
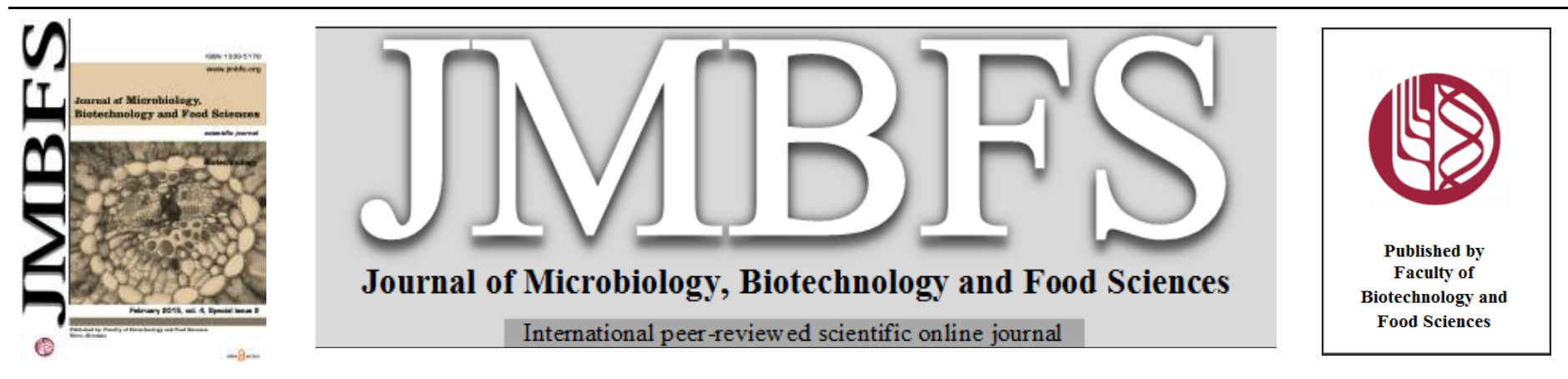

\title{
CHANGES IN TURKEY SPERMATOZOZA MOTILITY PARAMETERS AFTER ADDITION OF COPPER SULPHATE IN VITRO
}

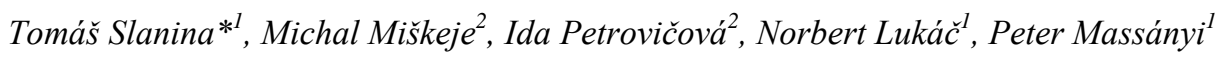

\author{
Address(es): MSc. Tomáš Slanina, \\ ${ }^{1}$ University of Agriculture in Nitra, Faculty of Biotechnology and Food Sciences, Department of Animal Physiology, Tr. A. Hlinku 2, 94976 Nitra, Slovak Republic, \\ phone number: +421 376414111 \\ ${ }^{2}$ Constantine the Philosopher University in Nitra, Faculty of Natural Sciences, Department of Zoology and Anthropology, Nábrežie mládeže 91,94974 Nitra, Slovak \\ Republic.
}

*Corresponding author: slaninatomas@atlas.sk

doi: 10.15414/jmbfs.2015.4.special2.98-100

\section{ARTICLE INFO}

Received 6. 11. 2014

Revised 19.11. 2014

Accepted 6. 1.2015

Published 2. 2. 2015

Regular article

OPEN $\partial_{\text {ACCESS }}$

\begin{abstract}
Copper as essential trace element is obligatory in many biological processes. Nevertheless higher concentrations of this metal are highly toxic for organisms at different levels and of course for spermatozoa. The aim of present work was to examine impact of copper sulphate on turkey spermatozoa motility parameters (line Big 6) during in vitro incubation at $41^{\circ} \mathrm{C}$. Four concentration of $\mathrm{CuSO}_{4}$ : $\mathrm{M}^{-}-6.25$ $\mu \mathrm{g} . \mathrm{ml}^{-1} ; \mathrm{M} 2-12.5 \mu \mathrm{g} . \mathrm{ml}^{-1} ; \mathrm{M} 3-25.0 \mu \mathrm{g} . \mathrm{ml}^{-1} ; \mathrm{M} 4-50.0 \mu \mathrm{g} \cdot \mathrm{ml}^{-1}$ were investigated. The motility parameters were evaluated using the Computer Assisted Semen Analyzer system (program Sperm Vision ${ }^{\circledR}$ ) at four time periods: 0, 30, 60 and 90 minutes. Immediately at the beginning of incubation significantly lower values of progressive motility were detected in samples M3 ( $<<0.01)$ and M4 ( $<<0.001)$ compared to the control. Significantly lower values of motility and progressive motility were detected in samples M2 ( $<<0.05), \mathrm{M} 3$ and M4 $(p<0.001)$ in comparison to control after 30 minutes of incubation. In the samples M3 and M4 also significant decrease $(p<0.05$, $\mathrm{p}<0.01, \mathrm{p}<0.001)$ of velocity curved line, amplitude of lateral head displacement and beat cross frequency were observed. In the sample M1 significant increase of velocity curved line $(\mathrm{p}<0.001)$ and amplitude of lateral head displacement $(\mathrm{p}<0.05)$ in comparison to control at the time 0 was detected. Obtained data demonstrate that the high concentration of copper sulphate (from $12.5 \mu \mathrm{g} . \mathrm{ml}^{-1}$ ) decreases motility parameters of turkey spermatozoa during in vitro incubation at $41{ }^{\circ} \mathrm{C}$. The results also indicate that the addition of copper less than $6.25 \mu \mathrm{g} \cdot \mathrm{ml}^{-1}$ to the culture medium could be beneficial for the motility of turkey spermatozoa.
\end{abstract}

Keywords: Copper, spermatozoa, motility, turkey, CASA

\section{INTRODUCTION}

Copper is an essential trace element and it is a vital part of several enzymes (e.g., ferroxidases, cytochrome c oxidase, superoxide dismutase, tyrosinase, lysyl oxidase, and dopamine beta hydroxylase). The absorption depends on the amount ingested, its chemical form, and the composition of other dietary components such as zinc. Because copper is a highly reactive metal and thus harmful to the cells if present as free ions, the intracellular copper levels are strictly controlled by a number of integral transmembrane transporters, metallobuffers, and metallochaperones (Nordberg et al., 2007). Copper has a multilateral function in the organism. It is important in iron absorption, affects hemopoiesis, and activates fermentation (Massányi et al., 2005). Copper plays together with others metals (such as calcium, magnesium, zinc) an essential role in spermatogenesis and fertility (Slivková et al., 2009).

Trace elements can be added to animal feeding stuffs. Their conditions of use are subject to close control. For example, copper, can be added in various forms, including basic cupric carbonate, monohydrate $\left(\mathrm{Cu}\left(\mathrm{CH}_{3} \cdot \mathrm{COO}\right)_{2} \cdot \mathrm{H}_{2} \mathrm{O}\right)$ and cupric sulphate, pentahydrate $\left(\mathrm{CuSO}_{4} .5 \mathrm{H}_{2} \mathrm{O}\right)$, to the diets of fattening pigs up to 16 weeks of age, provided that the total (added plus background level) does not exceed $175 \mathrm{mg} \mathrm{Cu} \mathrm{kg}^{-1}$ of the complete feeding stuff. For other species and categories of farm animals, the total (added and background) level of copper in the complete diet must not exceed $35 \mathrm{mg} \mathrm{kg}^{-1}$ but for ovines the permitted upper limit is $15 \mathrm{mg} \mathrm{Cu} \mathrm{kg}^{-1}$ of complete feeding stuff (Fuller, 2004).

Information about the recommended ration of copper in the diet of turkey are variable. According to Blair (2008) and National Research Council (1994; National Academy of Sciences, Washington, DC) estimated nutrient requirements of male and female turkeys are $6.0-8.0 \mathrm{mg}$ copper per $\mathrm{kg}$ diet (90\% moisture basis). Fuller (2004) states 20 - $50 \mathrm{mg}$ of copper per $\mathrm{kg}$ feed for turkey diets, depending on the age of turkeys.

With the increasing public concern of bacterial resistance to antibiotics, animal production industries are looking at subtherapeutic antibiotics alternatives that have antimicrobial properties, maintain intestinal health, and allow for optimal growth. Copper has received considerable attention due to its antimicrobial properties that improve performance in animals when fed over the minimum requirement. Studies have shown that supplementation with various $\mathrm{Cu}$ sources (e.g., $\mathrm{Cu}$ sulphate, $\mathrm{Cu}$ citrate, or $\mathrm{Cu}$ chloride) increases growth in poultry (Arias and Koutsos, 2006). The turkey breeders used 200 grams of copper sulphate per 400 litres of water during the gastrointestinal problems.

The toxicity of copper and another several metals, including iron, cobalt, and lead, may be mediated through oxidant-based and free-radical-based mechanisms, leading to oxidative stress. These metals increase the production of reactive oxygen species, decrease the levels of glutathione and other antioxidants (including selenium and zinc), affect the protective antioxidant enzymes by interfering with the metabolism of the specific metal(s) essential for the enzyme activity (such as $\mathrm{Cu}$, Zn-dependent superoxide dismutase, Se-dependent glutathione peroxidase, Fe-dependent catalase), enhance cell membrane lipid peroxidation, cause apoptosis, and contribute to oxidative DNA damage (Nordberg et al., 2007).

The trace element copper has been identified as a highly toxic element for spermatozoa. It is known to affect spermatozoa motility in humans, and experimental implantation of copper in the epididymis, vas deferens, and scrotum of mammals has been demonstrated to affect fertility detrimentally (Eidi $\boldsymbol{e t}$ al. 2010). Its role in the spermatozoa is unclear, but copper appears to be involved in spermatozoa motility and it may also act at the pituitary receptors which control the release of luteinizing hormone. In the seminal fluid, the level of copper appears to fall in cases of azoospermia and to increase in oligo- and asthenozoospermia (Roychoudhury and Massanyi, 2014).

Therefore the purpose of this work was to examine the effects of copper sulphate $\left(\mathrm{CuSO}_{4} .5 \mathrm{H} 2 \mathrm{O}\right)$ on turkey spermatozoa motility parameters in vitro. 


\section{MATERIAL AND METHODS}

\section{Biological materia}

In this study the semen was obtained by penal massaging of the turkeys of the line Big 6 (BUT - British United Turkeys Ltd., Chester, United Kingdom) Semen samples were a mixture of several groups of identical individual turkeys $(\mathrm{n}=5)$

\section{Sample preparation}

Semen was diluted in a ratio of 1 part of semen and 100 parts of physiologica solution (Sodium chloride 0.9\% Braun, B. Braun Melsungen AG, Melsungen, Germany) - control group (C). At the same ratio semen was diluted with four different concentrations of $\mathrm{CuSO}_{4} .5 \mathrm{H}_{2} \mathrm{O}$ (Sigma-Aldrich, St. Louis, USA) solution: M1 - 6.25 $\mu \mathrm{g} . \mathrm{ml}^{-1}$; M2 - $12.5 \mu \mathrm{g} . \mathrm{ml}^{-1}$; M3 - $25.0 \mu \mathrm{g} . \mathrm{ml}^{-1}$; M4 - 50.0 $\mu \mathrm{g} . \mathrm{ml}^{-1}$ diluted with the physiological solution. All samples were cultured at $41^{\circ} \mathrm{C}$ and measured at four time periods: $0 ; 30 ; 60$ and 90 minutes. The experiment was realized in 6 replicates.

\section{Analytical method}

Samples were evaluated using a Computer Assisted Semen Analyzer (CASA) system - Sperm Vision ${ }^{\circledR}$ (Minitub, Tiefenbach, Germany) equipped with microscope (Olympus BX 51, Japan) to assess the spermatozoa motility. Each sample was placed into Makler Counting Chamber ${ }^{\circledR}($ depth $10 \mu \mathrm{m}$, Sefi-Medica Instruments, Germany). In the pesent study, the following parameters were evaluated: total motile spermatozoa (MOT) [\%], progressively motile spermatozoa (PRO) [\%], velocity curved line (VCL) $\left[\mu \mathrm{m} . \mathrm{s}^{-1}\right]$, amplitude of latera head displacement $(\mathrm{ALH})[\mu \mathrm{m}]$ and beat cross frequency $(\mathrm{BCF})[\mathrm{Hz}]$. Motility parameters were evaluated from minimum seven fields of Makler Counting Chamber within each measurement by the CASA system.

\section{Statistical analysis}

Obtained data were statistically analysed using PC program Excel and a statistics package GraphPad 5 using t-test. Statistical significance was indicated by $p$ values of less than $0.05 ; 0.01$ and 0.001 .

\section{RESULTS AND DISCUSSION}

The results of all tested parameters of motility are presented in the Figures $1-5$ Percentage of spermatozoa motility (MOT) at the time 0 was without significant differences (Figure 1). Even in the sample M1 (6.25 $\mu \mathrm{g} . \mathrm{ml}^{-1}$ of copper sulphate) slight increase of motility in comparison to the control was detected. However after 30 minutes of incubation a negative effect of copper on spermatozoa motility was observed. Significantly lower values were detected in samples M2 ( $\mathrm{p}<0.05), \mathrm{M} 3$ and M4 ( $<0.001)$ compared to control. The higher temperature of incubation $41^{\circ} \mathrm{C}$ incurred considerable decrease of motility in all experimenta samples in comparison to the time 0 . Significantly higher percentage of motility was detected also in control sample than in samples M1 and M2 after 60 minutes of culture.

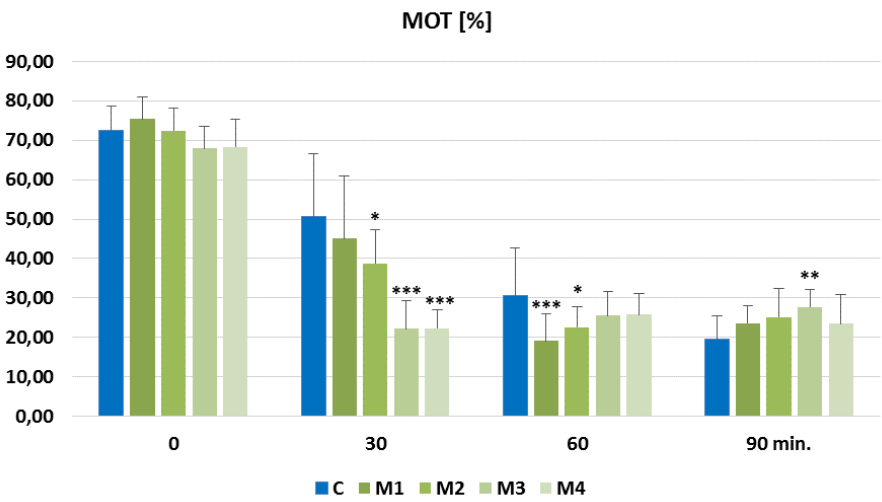

Figure 1 Spermatozoa motility $(\%)$ after copper sulphate addition. Significan differences $* p<0.05 ; * * p<0.01 ; * * * p<0.001$

Measurement of progressive spermatozoa motility (PRO) showed statistically significant difference immediately at the beginning of incubation (Figure 2). The values of samples M3 (40.71\%; $\mathrm{p}<0.01)$ and M4 (40.04\%; $\mathrm{p}<0.001)$ were significantly lower in comparison to the control $(51.08 \%)$. Increase in these differences was observed after 30 minutes: $\mathrm{C}-25.30 \%$; M3 - 3.6\%; M4 - 3.72\% $(\mathrm{p}<0.001)$. Significant decrease of this parameter was detected also in the sample M2 ( $<<0.05)$. Significantly lower values of progressive motility were detected in all experimental samples compared to control at the time 60 and in the samples M3 and M4 at the time 90 minutes.

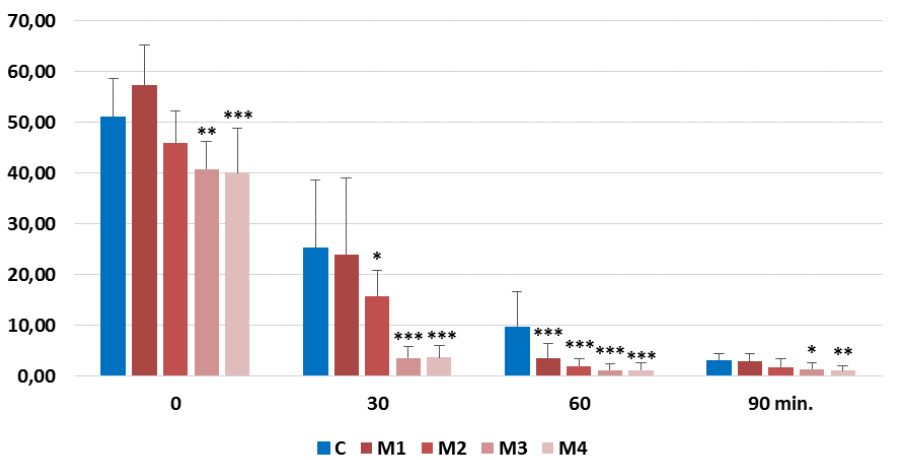

Figure 2 Spermatozoa progressive motility (\%) after copper sulphate addition Significant differences $* p<0.05 ; * *_{p}<0.01 ; * * * p<0.001$

Analysis of velocity curved line (VCL) proved significantly lower values in samples M3 $(\mathrm{p}<0.001)$ and M4 $(\mathrm{p}<0.001)$ at the time $30\left(\mathrm{M} 3-30.50 \mu \mathrm{m} . \mathrm{s}^{-1} ; \mathrm{M} 4\right.$ $\left.-33.52 \mu \mathrm{m} . \mathrm{s}^{-1} ; \mathrm{C}-84.77 \mu \mathrm{m} . \mathrm{s}^{-1}\right)$ and 60 (M3 - $16.76 \mu \mathrm{m} . \mathrm{s}^{-1} ; \mathrm{M} 4-20.13 \mu \mathrm{m} . \mathrm{s}^{-1}$; $\left.\mathrm{C}-56.09 \mu \mathrm{m} \cdot \mathrm{s}^{-1}\right)$. Between the samples $\mathrm{C}$ and $\mathrm{M} 2$ no significant difference was observed. Nevertheless, significantly higher velocity $(\mathrm{p}<0.001)$ was detected in the sample $\mathrm{M} 1$ than in sample $\mathrm{C}$ at the beginning of incubation (Figure 3 ). Amplitude of lateral head displacement (ALH) showed balanced values (Figure 4). Significant difference $(p<0.05)$ was observed between the samples M1 and $C$ at the time 0 . The higher values were detected in the sample M1 $(4.29 \mu \mathrm{m})$ compared to control $(3.99 \mu \mathrm{m})$. Significantly lower values were found only in the sample M3 in comparison to control at the time 30 and 60 minutes.

Analysing the beat cross frequency $(\mathrm{BCF})$ significant differences were not detected in the samples M1 and M2. Significantly lower values were detected in samples M3 and M4 than in the control only at the time 30 (Figure 5).

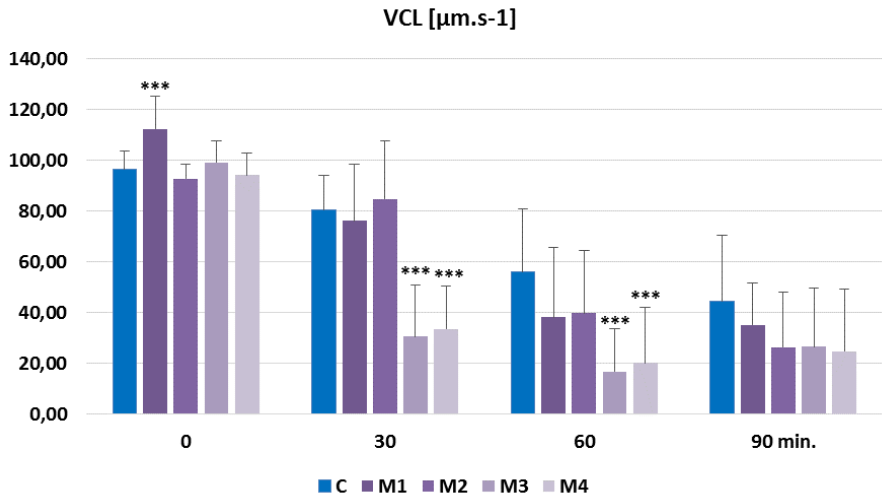

Figure 3 Velocity curved line $\left(\mu \mathrm{m} . \mathrm{s}^{-1}\right)$ after addition of copper sulphate Significant differences $* p<0.05 ; * * p<0.01 ; * * * p<0.001$

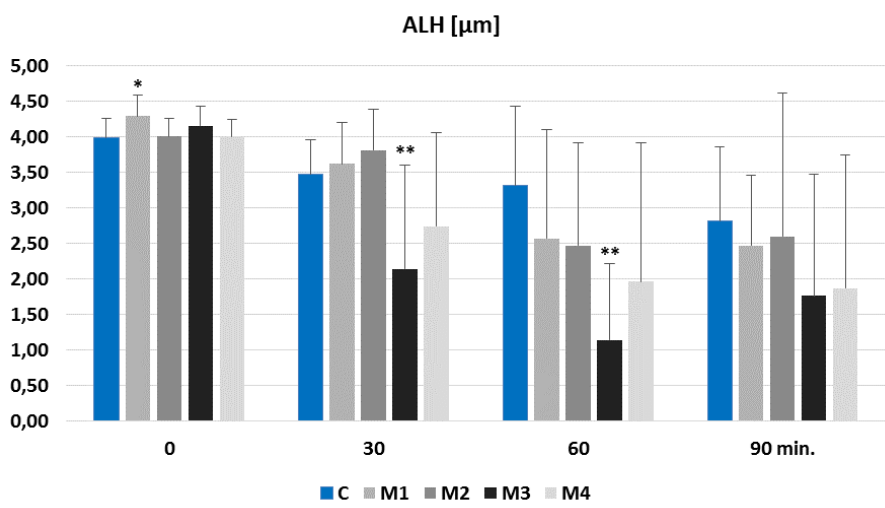

Figure 4 Amplitude of lateral head displacement $(\mu \mathrm{m})$ after addition of copper sulphate. Significant differences $*_{p}<0.05 ; * * p<0.01 ; * * * p<0.001$ 
BCF $[\mathrm{Hz}]$

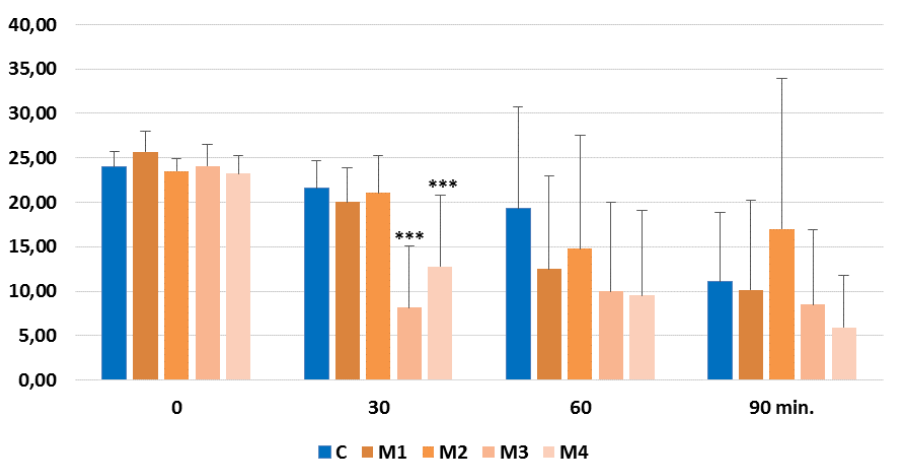

Figure 4 Beat cross frequency (in $\mathrm{Hz}$ ) after addition of copper sulphate. Significant differences $* p<0.05 ; * * p<0.01 ; * * * p<0.001$

The negative effect of copper on mammalian spermatozoa but not on avian spermatozoa was described in several studies. The rats exposed to copper (II) chloride aerosol by inhalation for 4 months displayed, at a copper concentration of $2.5 \mathrm{mg} \cdot \mathrm{m}^{-3}$ significantly, albeit not dose-dependently reduced blood concentrations of their sexual hormones, i.e. luteinizing hormone, folliclestimulating hormone and prolactin. There was a significantly increased incidence of spermatozoa mortality and abnormality. At a copper concentration of 19.6 $\mathrm{mg} . \mathrm{m}^{-3}$, overt signs of toxicity (no further details) and significant decreases in testicular weight, spermatozoa motility, as well as testosterone and estradiol levels in peripheral blood were observed (Anonym, 2012).

The results of the study of Babaei et al. (2012) demonstrated that copper intake with dose $100 \mathrm{mg} \cdot \mathrm{kg}^{-1}$ is able to have toxic effects from $14^{\text {th }}$ day on testes of rats. They showed that administration of copper damaged Sertoli cells as well as spermatogonia and these could be one of the explanations for impaired spermatogenesis and meiotic index.

The toxicity of copper at the molecular level can be explained by its direct effects on the structure and function of proteins, membranes, and DNA as well as by the reactivity of the oxygen radicals formed in the copper redox cycle (Anonym 2012)

Kňažická et al. (2010) analysed the motility of bovine spermatozoa afte addition of copper sulphate. They tested $62.5 ; 125 ; 250 ; 500 ; 1000 \mu \mathrm{M} . \mathrm{ml}^{-1}$ of copper and samples were incubated at $22^{\circ} \mathrm{C}$. Significant differences were observed already at the beginning in the all samples besides the lowes concentration of copper $\left(62.5 \mu \mathrm{M} . \mathrm{ml}^{-1}\right)$. After 2 hours of incubation the highes motility were found in sample with $62.5 \mu \mathrm{M} . \mathrm{ml}^{-1}$ of copper sulphate $(10.72 \%)$ in comparison to the control $(83.55 \%)$.

In our work much lower concentration of copper $\left(\mathrm{nM} \cdot \mathrm{ml}^{-1}\right)$ with similar effect on turkey spermatozoa were used. Higher sensitivity of turkey spermatozoa in comparison to the mammalian spermatozoa is caused probably by low quantity of seminal plasma or its complete absence. The composition of semen plasma plays important role in protection of spermatozoa against the adverse reaction of exogenous influence of environment.

The study of Roychoudhury et al. (2010) confirms adverse effects of high copper sulphate concentrations in rabbit semen on parameters of spermatozoa motility, morphology and cell membrane integrity. This work also indicates the lowest possible toxic concentration of copper $\left(3.70 \mu \mathrm{g} \cdot \mathrm{ml}^{-1}\right)$ to rabbit spermatozoa in relation to motility.

From animal experiments there is evidence that copper salts impair reproductive performance and that they are embryo- or foetotoxic, or teratogenic at higher doses. Soluble copper salts are not mutagenic in bacteria. Genotoxicity studies on mammalian cells in vitro revealed positive as well as negative results (Anonym, 2012).

The results of Tabassomi and Alavi-Shoushtari (2013) showed that coppe additive at the rate of $0.032 \mathrm{mg} . \mathrm{l}^{-1}$ gives a better protection of water buffaloes spermatozoa through the process of dilution, equilibration and freeze-thawing than that in control and other $\mathrm{Cu}$ concentrations, while $0.064 \mathrm{mg} .1^{-1} \mathrm{CuSO}_{4}$ had deleterious effect on the spermatozoa. The highest tested concentration of copper sulphate $\left(0.064 \mathrm{mg} . \mathrm{l}^{-1}\right)$ in fresh semen showed significantly lower values of progressive motility in comparison to the control. However in the sample with adding $0.32 \mathrm{mg} . \mathrm{l}^{-1}$ of copper were observed higher values of progressive motility and viability compared to control. Similar tendency were detected by Roychoudhury et al. (2010). The lowest tested concentration of copper sulphate (3.63 $\mu \mathrm{g} . \mathrm{ml}^{-1}$ and $3.57 \mu \mathrm{g} . \mathrm{ml}^{-1}$ ) showed balanced values of motility parameters of rabbit spermatozoa. After 2 hours of incubation in these two concentration of copper significantly higher $(p<0.05)$ values of motility and progressive motility in comparison to control were observed.

In our work the higher percentage of progressive motility was detected in the sample M1 $\left(6.25 \mu \mathrm{g} . \mathrm{ml}^{-1}\right)$ in comparison to the control. This sample with the lowest concentration of copper showed significantly higher values of VCL and ALH compared to control at the beginning of incubation. These results suggests that specific low concentration of copper may have positive effect on spermatozoa motility.

\section{CONCLUSION}

It may be concluded that the high concentration of copper sulphate have negative effect on motility parameters of turkey spermatozoa during in vitro incubation at $41^{\circ} \mathrm{C}$. The concentration of 50 a $25 \mu \mathrm{g} \cdot \mathrm{ml}^{-1}$ significantly decreased $(p<0.001)$ motility parameters after 30 minutes of incubation. The concentration of $12.5 \mu \mathrm{g}$ $\mathrm{CuSO}_{4}$ per $\mathrm{ml}$ is also toxic for the turkey spermatozoa. However lower concentration of copper sulphate (less than $6.25 \mu \mathrm{g} \cdot \mathrm{ml}^{-1}$ ) have no negative impact on turkey spermatozoa motility parameters, even they may have also positive effect.

Acknowledgments: This work was supported by a VEGA project No. 1/0532/11 and VEGA project No. 1/0042/12. The research leading to these results has received funding from the European Community under project no 26220220180 Building Research Centre "AgroBioTech". We would like to thank A. Koronczi for technical assistance.

\section{REFERENCES}

ANONYM. 2012. Copper and its inorganic compounds [MAK Value Documentation, 2006]. The MAK Collection for Occupational Health and Safety. 44-72. http://dx.doi.org/10.1002/3527600418.mb744050e0022

ARIAS, V. J., KOUTSOS, E. A. 2006. Effect of Copper Source and Level on Intestinal Physiology and Growth of Broiler Chickens. Poultry Science, 85(6), 999-1007. http://dx.doi.org/10.1093/ps/85.6.999

BABAEI, H., KHEIRANDISH, R., EBRAHIMI, L. 2012. The effects of copper toxicity on histopathological and morphometrical changes of the rat testes. Asian Pacific Journal of Tropical Biomedicine, 2(3), 1615-1619. http://dx.doi.org/10.1016/s2221-1691(12)60463-8

BLAIR, R. 2008. Nutrition and Feeding of Organic Poultry. Trowbridge

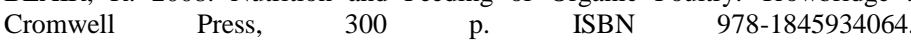
http://dx.doi.org/10.1079/9781845934064.0000

EIDI, M. - EIDI, A. - POUYAN, O. - SHAHMOHAMMADI, P. - FAZELI, R. - BAHAR, M. 2010. Seminal plasma levels of copper and its relationship with seminal parameters. Iranian Journal of Reproductive Medicine, 8(2), 60-65

FULLER, M. F. 2004. The Encyclopaedia of Farm Animal Nutrition. Wallingford : CABI Publishing, 606 p. $\quad$ ISBN $\quad 0 \quad 85199369$ http://dx.doi.org/10.1079/9780851993690.0000

KŇAŽICKÁ, Z., TVRDÁ, E., LUKÁČ, N., FORGACS, Z., KERTI, A. 2010 The effect of toxic concentrations of copper on the cell viability in vitro. Mende Net 2010 (proceeding of the work of the International Scientific Conference) Brno : 888-898.

MASSÁNYI, P., TRANDŽÍIK, J., NAD, P., SKALICKÁ, M., KORÉNEKOVÁ, B., LUKÁČ, N., FABIŠ, M., TOMAN, R. 2005. Seminal Concentration of Trace Elements in Fox and Relationships to Spermatozoa Quality. Journal of Environmental Science and Health, Part A: Toxic/Hazardous Substances and Environmental Engineering, 40(5), 1097-1105. http://dx.doi.org/10.1081/ese200056166

NATIONAL RESEARCH COUNCIL 1994. Nutrient Requirements of Poultry, Ninth Revised Edition. National Academies Press : Washington , D.C., 176 p ISBN 978-0-309-04892-7.

NORDBERG, F. G., FOWLER, B. A., NORDBERG, M., FRIBERG, L. 2007. Handbook on the Toxicology of Metals. Burlington : Academic Press, $1024 \mathrm{p}$ ISBN 978-0123694133. http://dx.doi.org/10.1016/b978-012369413-3/50052-5

ROYCHOUDHURY, S. - MASSANYI, P. 2014. Introduction to Male Reproduction and Toxicity. Nitra : Slovak University of Agriculture in Nitra, 30 p. ISBN 978-80-552-1204-3.

ROYCHOUDHURY, S. - MASSANYI, P., BULLA, J., CHOUDHURY, MD. STRAKA, L., LUKAC, N., FORMICKI, G., DANKOVA, M., BARDOS, L. 2010. In vitro copper toxicity on rabbit spermatozoa motility, morphology and cell membrane integrity. Journal of Environmental Science and Health, Part A Toxic/Hazardous Substances and Environmental Engineering, 45(12), 1482 1491. http://dx.doi.org/10.1080/10934529.2010.506092

SLIVKOVÁ, J., POPELKOVÁ, M., MASSÁNYI, P., TOPORCEROVÁ, S. STAWARZ, R., FORMICKI, G., LUKÁČ, N., PATU ŁA, A., GUZIK, M. 2009. Concentration of trace elements in human semen and relation to spermatozoa quality. Journal of Environmental Science and Health, Part A: Toxic/Hazardous Substances and Environmental Engineering, 44(4), 370-375. http://dx.doi.org/10.1080/10934520802659729

TABASSOMI, M., ALAVI-SHOUSHTARI, S. M. 2013. Effects of in vitro copper sulphate supplementation on the ejaculated sperm characteristics in water buffaloes (Bubalus bubalis). Veterinary Research Forum, 4(1), 31-36. 